\title{
OSCAR HIJUELOS, NOVELISTA
}

POR

\author{
ILAN STAVANS \\ The City University of New York - Barch College
}

¿Humilladas, ignoradas, ofendidas? Muchopodría decirse de lainvisibilidad de las letras hispanas en Estados Unidos. Harto más conocidos son los ancestros de William Carlos Williams, George Santayana o John Dos Passos que los escenarios de Miguel Piñero o las fantasías de Rudolfo Anaya. ¿A qué se debe la abulia? Sabemos de Toni Morrison, Philip Roth y Maxine Hong Kingston pero fallamos al invocar siquiera un narrador chicano o una poeta nuyorriqueña. Una excepción es el cubano Oscar Hijuelos, cuya notoriedad ha acarreado una enfadosa exclusividad. Hay quien cree que es el único hispano que escribe; otros, menos insensatos, saben que no es cierto, pero presienten que es el único que lo hace bien. Guillermo Cabrera Infante aseguró una vez (o dicen que aseguró) que Orson Wells era una ballena; algo no muy diferente se rumorea de Hijuelos: que es un pendenciero, un Dirty Harry que le vendió su alma al establishment; que es gringo y no hispano; que es un prestidigitador. Obvio que todas éstas son envidias y necedades, porque Hijuelos es sólo un experto en el arte de transaccionar su trabajo, un cirujano que tocó un nervio sensible. Además, puesto que la inmortalidad literaria nada tiene de democrática-como en la jungla, sobrevive el más diestro y el menos capaz perece--, no importa quién es sino qué escribe y cómo.

Su efemérides afirma que nació en 1951, en Nueva York, y que es autor de dos títulos: Our House in the Last World y seis años después, The Mambo Kings Play Songs of Love, que ganó el premio Pulitzer. Su obra ha sido traducida a infinidad de idiomas, entre ellos al español, lo que me parece curioso aunque nada avergonzante porque Conrad también fue traducido al polaco y Nabokov, al ruso. Podría suponerse que Hijuelos escogió la lengua de Shakespeare, pero la verdad es que fue seleccionado por ella: temprano en su vida enfermó de nefritis y lo internaron en un sanatorio de Connecticut, al que entró en español y del cual salió en inglés. Desde entonces, no le queda otro remedio que ese bagaje. Sus jornadas, para bien o para mal, se desempeñan en el mismo cuadrilátero donde pelearon Theodore Dreiser y Stephen Crane.

José Bianco pensaba que la auténtica persona del escritor está en su obra y sólo en su obra. Quien conozca algo de la vida de Hijuelos sospechará con 
justicia que su primer título incluye cada pormenor de su pasado, cada dato encarnado en la figura de la familia Santinio. Su alter-ego se llama Héctor; es el segundo hijo de una pareja de inmigrantes cubanos, escribe poesía y tiene la identidad escindida. Su padre, Alejo, es alcohólico; su madre, Mercedes Sorrea, es también poeta y conoció a su marido en la isla, viajando con él al Nuevo Mundo, donde encontraron miseria, sufrimiento y discriminación. Estos tres sustantivos, odiosos cuando aparecen en la misma ecuación, apuntan a la elevada dosis de melodrama, sensiblería y kitsch. Porque como totalidad, el texto, que cubre unos cincuenta años (de 1929 a 1975), comienza en Holguín y termina en Nueva York, decepciona y aburre. Nicolás Kanellos, en un diccionario biográfico de 1989, dedicado a las letras hispanas en Norteamérica, lo califica como "una típica autobiografía étnica" que demuestra la asimilación del flanco cubano al mainstream nacional; además, lo contrasta con otros libros previos, todos ellos de cubanos exiliados que, luego del radical 1959, usaron la pluma como "arma de penetración y propaganda política". Francamente, se trata de una novela inofensiva.

Los rasgos estilísticos de Hijuelos, sin embargo, están claros: prosa acompasada y naturalista; abundancia de descripciones pintorescas de esquinas y tipos; narración progresiva y lineal, repleta de flash-backs; interés por el jazz, los bares, el sexo y el alcohol. (Algunas de estas aficiones, apenas insinuadas aquí - por ejemplo, la erótica-, adquirirán un acento en The Mambo Kings Play Songs of Love). El modelo literario detrás incluye al León Tolstoi de Anna Karenina, al Isaac Bashevis Singer de Die Mischpoche Moslikat y Cien años de soledad, tres ejemplos donde la urgencia es contar las peripecias de un árbol genealógico en un período histórico determinado. Al redactar, el ruso, el polaco y el colombiano revelaron partes silenciadas, oscuras de una época, y lo hicieron cada uno a su manera, examinandola sensibilidad humanaimperante. Hijuelos sustituye el estudio tempo-espacial y el examen del espíritu colectivo por una nostalgia abrumadora. Su único interés es retratar a la minoría cubana en su búsqueda del American Dream, pero lo hace sin pathos. Joyce solía afirmar que cada escritor selecciona su lector ideal; el de Hijuelos es el estadounidense que ignora el significado de palabras como "guayabera" o "pañuelo" - de ahí que aparezcan en ambos idiomas-y que no sabe tararear "Quiéreme mucho", "Balabú" o "La malagueña". Ello, supongo, no debería importar demasiado; después de todo, no es necesario saber lo que es un samovar para penetrar en el alma de Ivan Illych. El problema, sin embargo, es que Hijuelos parece haber escrito esta novela para turistas.

Diré en este párrafo algo sobre su educación. Había comenzado a escribir seriamente a los veinticuatro o veinticinco años, y primero lo había hecho para teatro. Admiraba a Israel Horowitz, el dramaturgo que redactó una de las mejores farsas que conozco, The Line, y había imitado sus felicidades. Aquellos experimentos avant-garde hoy son interesantes sólo para quienes hagan de Hijuelos tema de una disertación doctoral. Su verdadero aprendizaje le 
sobrevino durante sus años en The City University of New York, donde tuvo una carrera que incluyó como maestros a Joseph Heller, Susan Sontag y Donald Barthelme: al primero lo ignoró: la segunda, con su afán crítico, editaba y comentaba sus escritos, mientras el tercero (que ya había escrito Come Back, Dr. Caligari) lo introducía a Borges, Gabriel García Márquez y Julio Cortázar. $\mathrm{Su}$ estilo personal se forjó ante las inquisiciones de Barthelme, aunque (o porque) ambos caracteres no podían ser más diferentes: aquél era un cuentista apasionado por el detalle, un litterateur; éste, un novelista bohemio, algo etéreo, con un trepidante interés en el realismo racial. De esas clases salieron cuentos de espiritismo y magia que recuerdan Macondo y sus alrededores; asimismo, un par de ejercicios post-modernistas, uno de ellos titulado "Columbus discovering America", donde la tripulación del almirante genovés ve imágenes extraordinarias - los New Yorks Mets y el Empire State Building-. Siguieron abortos narrativos, cuentos rechazados por revistas académicas, borracheras, oficios marginales y desesperanza.... Hasta Our House at the End of the World, que si bien no pronosticaba una ilustre trayectoria, sirvió para exorcizar algunos fantasmas.

La madurez llega sin avisar. Si los Santinio carecen de relieve o relevancia, otra cosa ocurre con los hermanos de The Mambo Kings Play Songs of Love, que recrea el Manhattan de los cuarenta, cuando Benny Goodman y Artie Shaw fueron reemplazados por ritmos del Caribe y Brasil, entre ellos el mambo, la rumba, la zamba y el cha-cha-chá, cada cual con su respectivo danzón. Como un LP, el libro está dividido en "Lado A", cuyo escenario es el Hotel Splendor de 125th Street y Lenox Avenue una noche de 1980; y "Lado B", que toma lugar horas más tarde. La médula ósea la constituyen César ("suavecito") y Néstor ("el gallego") Castillo, conocidos como los reyes del mambo. Hay dosflash-backs, uno circunscrito en otro: en la introducción, Eugenio Castillo, sobrino de César e hijo del difunto Néstor, despierta a su tío porque en televisión proyectan por enésima vez el episodio de I Love Lucy en que tuvieron un minúsculo cameo; de hecho, la actuación representó el ápice en su carrera musical: Desi Arnaz, marido de Lucille Ball, los invitó a interpretar su famoso hit, "Bellísima María de mi alma". Segundo flash-back: César, carcomido por la nostalgia y el fracaso, está fumando y bebiendo en el Hotel Splendor; han pasado veinticinco años desde la aparición televisiva, la memoria se activa y recuerda las infinitas y agobiantes sesiones de amor con $s u$ Vanna Vane; el vínculo con su hermano y cómo ambos abandonaron en 1949 su natal provincia de Oriente para asentarse en el enclave cubano del alto Manhattan; su trabajo en una empacadora de alimento; sus respectivos desempeños musicales.

Como Don Quijote y Sancho, como Jacques y su maître, César representa el flanco distraído, jovial y hedonista; Néstor, el atormentado, gótico y poseído por los demonios del ayer. Surge en él una estremecedora infelicidad basada en la añoranza por un momento específico, uno en que conoció a María, una hermosa mujer de su adolescencia cubana; con tal de recobrarla, con tal de 
capturar su esencia, re-escribe veintidós versiones de una misma melodía. Los Castillo graban discos, escalan la jerarquía, hacen una gira. Pero Néstor sigue obsesionado y obtiene un fugaz respiro al casarse con Delores, una cubana inteligente que da a luz sus dos hijos, Eugenio y Leticia. Un día, mientras maneja un automóvil y César manosea a Vanna en el asiento trasero, el volante queda libre, hay un choque contra un árbol y Néstor muere en el accidente. César no se recupera emocionalmente y comienza su derrumbe. Al final, Eugenio, de vacaciones en Los Angeles, tiene la oportunidad de visitar a Desi Arnaz en su casa, evento que representa una apoteosis, una desilusión, el Eterno Retorno. Según una confesión personal, la conclusión proviene de un sueño de Hijuelos que invoca $A$ terceira margem do rio de João Guimaraes Rosa; soñó que veŕa a su padre muerto en un río; le gritaba, el hijo iba hacia él y notaba que en su joven epidermis florecía una infección; entonces el padre decía que las aguas del río le limpiarían la enfermedad; y era cierto, se bañaba en la corriente y quedaba curado.

No quiero (ni debo) irme sin mencionar la polémica en derredor a The Mambo Kings Play Songs of Love. Lawrence Durrell dijo una vez que sólo con gran vulgaridad se puede alcanzar el verdadero refinamiento, sólo de la impudicia se puede obtener ternura. La crítica, en especial algunos círculos homosexuales y feministas, dejó sentir su animosidad al denunciar las escenas sexuales en que la mujer es un mero fetiche y el pene una divinidad. Quizás con la única y notable excepción de Delores, sus mujeres, decía, son caricaturas inverosímiles y nimias, meras depositarias de semen masculino; y si bien es cierto que el libro parodia el machismo, también se deleita en sus aberraciones. Este epicureísmo abultado sin duda es una imperfección, pero hay otra menos perdonable: la abusiva extensión, que atosiga y cohíbe. Quien sortee estos obstáculos, sin embargo, sentirá placer y asombro ante la abundante y exquisita información histórica del Nueva York de pulso latino. Los ingredientes estructurales, sobre todo el televisor como puente transgeneracional, están yuxtapuestos en forma fascinante. Hijuelos trabajó en ellos seis años, época durante la cual vivió en Italia y viajó por Europa, Turquía y Africa; al regresar a Manhattan tuvo dificultades financieras y, durante casi cincuenta meses, acumuló notas y amontonó borradores. Vendió el manuscrito a Farrar, Straus (1) Giroux a partir de una centena de cuartillas y la editorial le dio un plazo breve para acabarlo.

¿Hay algún vestigio en Hijuelos del archi-comentado barroquismo cubano, ese estilo que, según Borges, deliberadamente agota (o quiere agotar) sus posibilidades y que linda con su propia caricatura? Ninguno. Si Alejo Carpentier anhelaba descifrar la realidad a través del lenguaje, y si José Lezama Lima usaba imágenes y metáforas para prefigurar un universo sobrenatural, en este escritor la única complejidad es la que deviene de reconocer y memorizar su firmamento de personajes, cada uno con sus respectivas motivaciones. Más que barroco, se trata de un novelista excesivo, 
inmoderado y hasta colosal. ¿Y qué decir de su inglés? Sin titubeos, que es muy suyo. Si quisiera, ahora mismo yo podría listar las plumas de procedencia iberoamericana o peninsular que en algún punto de su carrera dieron el salto a este vehículo anglosajón: comenzaría con Felipe Alfau, el autor que antes de la II Guerra Mundial dio a luz Locos. A Comedy of Gestures, un libro que fascinaba a Mary McCarthy, y poco más tarde Chromos, uno que entusiasma a Gregory Rabassa; seguiría con Borges, Carlos Fuentes, José Donoso; y terminaría con el Cabrera Infante acometedor e incisivo de Holy Smoke. Innecesario sería decir que, sin una sola excepción, todos y cada uno de los nombres de esta lista son dueños de un inglés libresco, adquirido; pero el de Hijuelos no, el suyo es hermoso, seguro, real, acreditado y castizo -un pasaporte.

Según Balzac, la mayor parte de las casualidades son premeditadas. Nicolás Kanellos, en el mencionado diccionario biográfico, profetizó que Our House at the End of the World representaría una puerta de entrada para los escritores hispanos al aparador literario norteamericano, por lo menos al comercial. Su insinuación hace suponer que después de (y gracias a) este cubano, por fin seremos capaces de un Saúl Bellow o un Ralph Ellison. Pero visualizar la inspiración como una tribuna igualitaria (me vuelve a la mente la palabra "democrática") es un cretinismo, una barbaridad. Quizás el significado del Pulitzer para The Mambo Kings Play Songs of Love sea que, como el Espíritu Santo, estas letras "minoritarias" pronto harán visible loinvisible. Por mi parte, extravagante y algo prodigioso; y que debemos juzgarlo como el artista que es, sin recelos ni infamias, y sobre todo sin contextos incrédulos. 
